\title{
THEME: SEXUAL HEALTH, HUMAN RIGHTS AND THE LAW
}

\section{Advancing sexual health through human rights: The role of the law}

\author{
Eszter Kismödi $^{\mathrm{a} *}$, Jane Cottingham ${ }^{\mathrm{b}}$, Sofia Gruskin ${ }^{\mathrm{c}}$ and Alice M. Miller ${ }^{\mathrm{d}}$ \\ ${ }^{a}$ Harvard Law School, Harvard University, Cambridge, MA, USA; ${ }^{b}$ Independent Consultant, \\ Geneva, Switzerland; ' Program on Global Health and Human Rights, Keck School of Medicine, \\ Gould School of Law, Institute for Global Health, University of Southern California, Los Angeles, \\ CA, USA; ${ }^{d}$ Global Health Justice Partnership of the Yale Law School and the School of Public \\ Health, Yale Law School, New Haven, CT, USA
}

(Received 19 October 2014; accepted 6 November 2014)

\begin{abstract}
Since the International Conference on Population and Development, definitions of sexuality and sexual health have been greatly elaborated alongside widely accepted recognition that sexual health requires respect, protection and fulfilment of human rights. Considerable progress has also been made in enacting or changing laws that affect sexuality and sexual health, in line with human rights standards. These measures include legal guarantees against non-discrimination and violence, decriminalisation of consensual sexual conduct and guaranteeing availability, accessibility, acceptability and quality of sexual health information and services to all. Such legal actions have had positive effects on health and specifically on sexual health, particularly for marginalised populations. Yet in all regions of the world, laws still exist which jeopardise health, including sexual health, and violate human rights. In order to ensure accountability for the rights and health of their populations, states have an obligation to bring their laws into line with international, regional and national human rights standards. These rights-based legal guarantees, while insufficient alone, are essential for effective systems of accountability, achieving positive sexual health outcomes and the respect and protection of human rights.
\end{abstract}

Keywords: sexual health; human rights; law; non-discrimination; accountability

\section{What ICPD established and where we are today}

For the first time in an intergovernmental agreement, the International Conference on Population and Development (ICPD) Programme of Action (POA) defined reproductive health and reproductive rights. Sexual health, 'the purpose of which is the enhancement of life and person relations, and not merely counselling and care related to reproduction and sexually transmitted diseases', was included as part of reproductive health (UN, 1994). And while the POA also enjoined governments and others to give full attention to meeting the 'educational and services needs of adolescents ... to deal ... with their sexuality' and to the promotion of 'mutually respectful and equitable gender relations', it did not elaborate on the various dimensions of sexuality, sexual health and sexual rights. In 1995, international consensus was reached at the Fourth World Conference on Women that 'the human rights of women include their right to have control over and decide freely and responsibly on matters related to their sexuality' (UN, 1996), a very important recognition, but still limited in scope and content.

*Corresponding author. Email: eszter.kismodi@gmail.com 
Since then, dramatic developments have occurred in the global understanding of sexuality and sexual health. While it encompasses some aspects of reproductive health such as contraception and abortion, many aspects of sexual health - including sexual pleasure, intimacy and the sexual health consequences of violence and female genital mutilation, as well as the complexities of sexual dysfunction - are not directly associated with reproduction. Sexual health extends beyond the reproductive years and cannot be adequately supported without a broadened understanding of sexuality. Further, social mobilisation on HIV and AIDS beginning in the early 1990s forced attention to the taboos, stigma and discrimination related to sexuality, while public health leaders and research, alongside these social movements, raised awareness of the importance of human sexuality and sexual behaviour, including people's ability to have fulfilling and pleasurable sexual relationships (World Health Organization [WHO], 2006).

There is now increasing recognition that sexual health cannot be achieved without the respect, protection and fulfilment of all human rights and that meeting human rights obligations is essential for social justice, sustainable development and public health (International Planned Parenthood Federation [IPPF], 2008; WHO, 2004, 2010a; World Association for Sexual Health [WAS], 2014). For example, an intergovernmental Latin American and Caribbean review of 20 years of ICPD implementation concluded that states must:

promote policies that enable persons to exercise their sexual rights, which embrace the right to a safe and full sex life, as well as the right to take free, informed, voluntary and responsible decisions on their sexuality, sexual orientation and gender identity, without coercion, discrimination or violence, and that guarantee the right to information and the means necessary for their sexual health, and reproductive health. (United Nations Economic Commission for Latin America and the Caribbean [UNECLAC], 2013)

A strong claim has also been made in the context of the post-2015 development agenda that due recognition should be given to sexual and reproductive health and rights in the sustainable development goals, since sexual and reproductive health and rights are critical dimensions of development and are a critical component of health and wellbeing of individuals (Temmerman, Khosla, \& Say, 2014).

While there is currently no formal political international consensus on the term 'sexual rights', the work of WHO and international organisations such as World Association for Sexual Health (WAS) and the International Planned Parenthood Federation (IPPF), among others, has led to an understanding that sexual rights are grounded in universal human rights that are already recognised in international and regional human rights documents and in national constitutions and laws (IPPF, 2008; WAS, 2014; WHO, 2010a). This conceptual understanding takes into account the significant development over the past two decades of human rights laws and standards relating to sexuality.

Considerable progress has been made in changing or enacting laws affecting sexual health, in line with human rights standards, although the opposite has been also observed. This is important because harmonising laws with human rights standards can foster the promotion of sexual health across and within various populations, while the negative health impact of laws that are in contradiction with human rights standards has been increasingly documented. Laws matter because they set the rules of social interactions (at macro- and inter-personal levels) and can provide the framework for implementation of sexual health-related policies, programmes and services. They can provide human rights 
guarantees, but they may also create limitations on health and rights. Either way, laws and regulations have an impact on the enjoyment of the highest attainable standard of sexual health. For example, laws that foster the dissemination of objective, comprehensive sexuality information, if implemented for all, contribute to people's knowledge of what protects or damages their sexual health, including where and how to seek further information, counselling and treatment if needed. On the other hand, laws that restrict access to health services by requiring third party authorisation for services for women and adolescents, for example, and laws that criminalise certain consensual sexual behaviour, effectively exclude or deter people from seeking and receiving the information and services they require and to which they have a right.

While actions are needed across many sectors, it is vital that people in the health sector understand how health, human rights and law interact, and their relevance to both individual and public health. In this paper, we examine some of these interactions, presenting concrete examples of legal changes and new standards related to a few key aspects: non-discrimination, criminalisation and access to information and services, and we point to how governments can and should be shaping the legal environment to meet their human rights obligations and improve sexual health.

\section{Box 1: Human rights law, human rights standards}

Human rights law is codified in international and regional treaties such as the Covenant on Economic, Social and Cultural Rights and the European Convention on Human Rights, and in national constitutions and laws. Treaties become legally binding through ratification and incorporation into national constitutions and laws. A decision of international courts such as the International Criminal Court, and regional courts such as the European Court of Human Rights, is binding on the nation that receives the decision. Such decisions are also authoritative interpretations of what the treaty means and other countries often adjust their laws to conform. Human rights standards include not only law but also norms and principles which can be used to guide state action and which are derived from a variety of sources such as the statements of United Nations treaty monitoring bodies (e.g., the Committee of the Rights of the Child that monitors state compliance with the Covenant on the Rights of the Child). These authoritative bodies have produced key views, findings and recommendations that constitute human rights standards for the protection of human rights related to sexuality and sexual health as demonstrated throughout this article.

\section{Law and its role in countering discrimination}

Inequality among and between persons and groups is a strong predictor of ill health, including sexual health (see the paper by Snow, Laski, \& Massy, 2014). Inequalities, manifested in people's differential access to services and resources, ability to participate in the making of laws and policies and the ability to seek remedies for abuses committed against them, are often the result of discrimination (WHO, 2010a).

Discrimination is understood in international human rights treaties to mean any adverse distinction, exclusion, restriction or preference which is based on any ground such as 'race, colour, sex, language, religion, political or other opinion, national or social 
origin, birth or other status' and which has the effect or purpose of impairing or nullifying the recognition, enjoyment or exercise of rights (United Nations [UN], 1966).

Recent developments in international human rights standards make clear that the grounds on which discrimination is prohibited are non-exhaustive and include disability, age, marital and family status, sexual orientation, gender identity and health status (e.g., HIV) (UN Committee on Economic, Social and Cultural Rights [CESCR], 2009; UN Committee on the Elimination of Discrimination against Women [CEDAW], 2010) all of which are closely associated with sexual health. Several countries have recently made some of these grounds explicit in their legislation (Council of Europe, 2011). Among other examples, the anti-discrimination law in Serbia recognises equality of people and includes, among the grounds for non-discrimination, gender, gender identity and sexual orientation as well as health, marital and family status (National Assembly of the Republic of Serbia, 2009).

Discrimination often encompasses more than one form of exclusion or stigma and states are responsible for having laws in place to prevent and address such discrimination (Council of Europe, 2011; Organization of American States General Assembly, 2013). Poor women and girls belonging to ethnic minorities, for example, are often burdened by both gender and race or socioeconomic-linked discrimination and exclusion (CEDAW, 2011). Denial of access to safe and legal abortion affects all women, but poorer or minority women and girls are more likely than others to face the health consequences, including mortality, of unsafe abortion, and they and their families face more difficulties in obtaining redress and remedies (CEDAW, 2009).

In addition to having explicit guarantees of non-discrimination, states are obligated to review and revise laws to ensure they are not perpetrating either direct or indirect discrimination (CESCR, 2009). For example, laws that set lower age limits for girls than for boys to marry directly discriminate on the ground of sex (CEDAW, 1999). In addition, laws indirectly discriminate when they create unfair and arbitrary distinctions in practice, even if the excluded population group is not named in the law. For instance, indirect discrimination against same-sex couples can be found in laws limiting insurance or other social benefits to married spouses in those contexts where the law limits the right of marriage to opposite sex partners (Dulitsky \& Zimmerman, 2013; Inter-American Court of Human Rights, 2012; International Council on Human Rights Policy, 2009). Laws often embody cultural understanding of social roles that are deeply rooted in genderbased discrimination. For example, rape has traditionally been understood as 'unlawful' sexual intercourse by a man with a woman who is not his wife, through force and/or against her will, and involving vaginal penetration by a penis. Under such definitions, women married to the alleged rapist, men and boys, and many transgender individuals cannot make legal claims to have been raped. Over the past decades, international criminal law has elaborated the elements of the crime of rape, which radically change this traditional understanding. These elements include coercive 'invasion' or 'conduct resulting in penetration, however slight, of any part of the body of the victim ... with a sexual organ, or of the anal or genital opening of the victim with any object or any other part of the body' (International Criminal Court [ICC], 2011). Under international law today, rape laws must apply to a person of any sex or gender, whether perpetrator or victim (ICC, 2011).

Moreover, international and regional human rights law now recognises that rape can occur within marriage and is a crime in all circumstances (CEDAW, 2002; ECtHR, 1995). The African Women's Protocol, for example, clearly indicates that immunity cannot be granted to husbands accused of rape (African Union, 2003). The International Criminal 
Court established that the evidence required to prosecute rape no longer requires corroboration of a victim's testimony by third parties (International Criminal Court Assembly of States Parties, 2002), a requirement historically linked to the belief that female complainants are unreliable. Many national laws have been amended over the past decade in line with these human rights standards. One example is the amendment of Thailand's Criminal Code in 2007 to expand the definition of rape to include rape within marriage, people of all genders and all types of sexual penetration (Kingdom of Thailand, 2007). Similarly, in South Africa, rape is now recognised as a crime committed by a person of any gender against another person of any gender, any act of penetration is considered and evidence of physical force is not required (Republic of South Africa, 2007).

\section{Misuse of criminal law and the harms caused to health and rights}

Because criminal laws are the strongest expression of the state's power to punish certain acts and behaviours, states must ensure full protections for defendants and careful attention to the needs of victims. In regard to sexuality and health, it is important to distinguish between behaviour that is harmful to others, such as rape and coerced sex, and that which is not, such as consensual sex outside of marriage, consensual same-sex conduct, transactional sex between consenting persons, such as sex work, sexual activity among and between older adolescents, conduct related to gender-expression such as cross-dressing, as well as seeking or providing sexual and reproductive health information and services, such as for contraception and abortion. Use of criminal laws in relation to an expanding range of otherwise consensual sexual conduct has been found to be discriminatory by international, regional and national human rights bodies, often together with violations of other human rights, such as rights to privacy, selfdetermination and human dignity and the significant impediment to the realisation of the right to health (CEDAW, 1999; ECtHR, 1981; UN 2011a, 2011b; UN Human Rights Committee [HRC], 1994).

Criminalisation of consensual sexual acts and behaviour has negative consequences for health, including sexual health. Persons whose consensual sexual behaviour is deemed a criminal offence may try to hide it from health workers and others, for fear of being stigmatised, arrested and prosecuted. This may deter people from using health services, resulting in serious health problems such as untreated sexually transmitted infections and unsafe abortions, for fear of negative reactions to their behaviour or health status (Day \& Ward, 2007; Global Commission on HIV and the Law, 2012; Reckart, 2005; UN, 2011b; Joint United Nations Programme on HIV/AIDS [UNAIDS], 2013). In many circumstances, those who do reach health services report discrimination and ill-treatment by health care providers (Rutledge, Abell, Padmore, \& McCan, 2009; Sayles, Wong, Kinsler, Martins, \& Cunningham, 2009). Further, criminalisation is linked to high levels of harassment and violence, reported by lesbian, gay, transgender people and sex workers around the world (Blankenship \& Koester, 2002; Crago, Rakhmetova, Klaradafov, Islamova, \& Maslove, 2008; India HIV/AIDS Alliance, 2011; Mayhew et al., 2009; Pauw \& Brener, 2003; WHO, 2005a). Often this violence is perpetrated by law enforcement authorities, meaning that people have little if any recourse to protection or investigation of such crimes committed against them (Benoit \& Millar, 2001; Crago et al., 2008; Jeffrey \& Sullivan, 2009; Karandikar \& Moises, 2010; Lutnick \& Cohan, 2009; Miller, 2002). 
International human rights bodies increasingly call for decriminalisation of consensual sexual acts and behaviour, and national courts play an important role in striking down discriminatory criminal laws with potentially negative health effects. Rights to privacy, human dignity, non-discrimination and equality have been upheld by numerous courts in connection with decriminalisation of same-sex conduct during the past two decades, and the protection of health has been raised as a concern in many of their decisions. In a ground-breaking case, Toonen v. Australia (1994), for example, the Human Rights Committee determined that the right to non-discrimination on the ground of sex includes sexual orientation. The Committee held that the Tasmanian Criminal Code, as applied to same-sex sexual behaviour between men, violated the right to be free from arbitrary interference with private life. The provisions had been justified on public health grounds, intended in part to achieve the aim of preventing the spread of HIV/ AIDS. The Committee dismissed this justification, based on a review of extensive public health evidence showing that such application of the Criminal Code in no way prevented the spread of HIV/AIDS, but rather has the potential to have the contrary effect. The Committee explained that, 'the criminalization of homosexual practices cannot be considered a reasonable means nor proportionate measure to achieve the aim of preventing the spread of HIV/AIDS' (HRC, 1994). Following this decision, the Australian Government enacted the Human Rights (Sexual Conduct) Act (1994), in which same-sex sexual conduct is no longer criminalised (Commonwealth of Australia, 1994). The international ruling marked a major evolution of law related to sexual orientation and has been used as a basis of some states' law reform on same-sex conduct (UN, 2011a), including Fiji (Republic of Fiji High Court, 2005) and South Africa (Republic of South Africa Constitutional Court, 1998). Despite this encouraging development, same-sex sexual behaviour and acts remain criminalised in 76 member states of the UN, roughly $40 \%$ of all UN member states (Itaborahy \& Zhu, 2013).

Health and safety considerations have also played a key role in the revision of criminal laws applied to other aspects of consensual sexual behaviour. The Prostitution Reform Act (2003) of New Zealand, for example, decriminalised sex work specifically to: safeguard the human rights of sex workers and protect them from exploitation; promote their welfare, occupational health and safety including through access to information; promote public health; and prohibit sex work by persons under age 18 and all coerced sex work. This approach, based on labour rights, uses general workplace health and safety legislation and administration, rather than criminal law. The Act requires every operator of a sex work business to take all reasonable steps to provide oral or written health information to workers and clients, and brothels must display health information prominently (New Zealand Public Act, 2003).

The positive health impact of decriminalising sex work has been documented, especially when health and safety standards are also put in place (Commonwealth of Australia State of Victoria, 2006; New South Wales Government, 2001; O'Connor, Berry, Rohrsheim, \& Donovan, 1996). For example, a study conducted in Victoria, Australia concluded that, where prostitution is decriminalised and structural supports exist for safer sexual practices, women sex workers experienced lower levels of sexual violence than sex workers in environments without such provisions and also little risk of HIV or STI to themselves or their clients (Commonwealth of Australia State of Victoria, 2006). Despite this strong evidence, and the existence of national laws decriminalising the sale and purchase of sex, international human rights law as yet has no clear consensus on the role of the criminal law. At a minimum, however, states must ensure that people in sex work are free from violence or discrimination, whether by state agents or private persons, and 
that they have access to equal protection of the law (UN, 2010). The health needs and rights of women engaged in sex work require special attention, particularly where their illegal status renders them vulnerable to violence (CEDAW, 1999; Committee on the Elimination of Discrimination against Women [CEDAW], 1992; UN, 2010). According to international human rights law and standards, forcible or fraudulent movement into sex work is a violation of human rights and is prohibited (UN, 2000; UN Committee on the Rights of the Child [CRC], 2000).

\section{Legal guarantees for access to sexual health information and services}

Laws, such as health laws, administrative laws, population laws or civil codes, can play important roles in the provision of and accessibility of sexual health information and services.

Some states have established specific constitutional protections for access to information and services related to sexuality and sexual health. The Constitution of the Republic of South Africa includes the right of access to health services, including reproductive health services, and the right not to be refused emergency medical treatment (Republic of South Africa, 1996). In Portugal, the Constitution explicitly guarantees a right to family planning with respect for individual freedom (Assembleia da Republica, 1976). The implementing law requires that condoms be available at schools through vending machines because of their importance in preventing HIV and other STIs (Portuguese Republic, 1999). A further legal instrument requires all hospitals that provide obstetric or gynaecological care in Portugal's national health service to offer family planning counselling and ensure the free distribution of contraception (Portuguese Republic, 2000). The removal of legal barriers to accessibility of sexual and reproductive health services has been increasingly shown to result in positive outcomes for health. For instance, accumulated evidence on the impact of restrictive abortion laws on maternal mortality and morbidity shows that the removal of such restrictions results in reduction of maternal mortality due to unsafe abortion (David, 2002; Jewkes, Brown, Dickson-Tetteh, Levin, \& Rees, 2002; Jewkes \& Rees, 2005; Suvedi et al., 2009) and that where abortion is legal on broad socioeconomic grounds and on a woman's request, and where safe services are accessible, both unsafe abortion and abortion-related mortality and morbidity are reduced (Bartlett et al., 2004; Berer, 2004; Jewkes, Rees, Dickson, Brown, \& Levin, 2004; WHO, 2008). These findings demonstrate eloquently how laws and policies can have a positive impact on sexual health. For health and human rights reasons, therefore, more than 30 countries have liberalised their laws over the past three decades to provide abortion on an expanded number of grounds (Boland \& Katzive, 2008; Cook \& Dickens, 2008).

In stark contradiction to these positive developments are laws which impair access to sexual health services, including laws that require a husband's authorisation before a wife can get contraception, or at least one parent's authorisation for adolescents to get information and services for a sexually transmitted infection, contraception or legal abortion. Such restrictions, which remain common, constitute serious barriers for women and adolescents and also violate their rights to non-discrimination, to health and to privacy (CEDAW, 1999).

Other laws impede access to medicines that are essential for sexual and reproductive health. For example, the emergency contraceptive levonorgestrel, which reduces the chance of pregnancy by $60-90 \%$ when used within five days after unprotected intercourse (WHO, 2005b), is included in the WHO Model List of Essential Medicines 
(WHO, 2011a). It is available in many countries, sometimes on prescription but increasingly over the counter, which reduces costs and makes it more readily accessible. Studies from British Columbia, France, Ghana, Great Britain, Hong Kong, India, Scotland and the USA, among others, show that women use emergency contraception on time and effectively when it is available without a prescription (Ellertson et al., 2001; Harper, Cheong, Rocca, Darney, \& Raine, 2005; Jackson, Schwarz, Freedman, \& Darney, 2003; Lo, Fan, Ho, \& Glaser, 2004; Lovvorn et al., 2000; Marston, Meltzer, \& Majeed, 2005; Moreau, Bajos, \& Trussell, 2006; Soon, Levine, Osmond, Ensom, \& Fielding, 2005).

In some countries, however, policies providing for registration of levonorgestrel have been challenged on the grounds that it acts as an abortifacient and thus is prohibited by the constitution. When such a case arose in Colombia, the highest administrative court overturned the challenge, ruling that levonorgestrel had only contraceptive effects and that its registration and distribution should therefore proceed (Council of State of the Republic of Colombia, 2002). Similar rulings have been made in Mexico (Supreme Court of the United Mexican States, 2010), Peru (Constitutional Tribunal of the Republic of Peru, 2006) and England and Wales (England and Wales High Court of Justice, 2002). All these rulings are in line with international human rights law, which recognises that availability and accessibility of essential medicines is a core element of the right to the highest attainable standard of health (Hogerzeil, Samson, Casanovas, \& Rahmani-Ocora, 2006; UN Committee on Economic, Social and Cultural Rights [CESCR], 2000).

In many countries, laws also impose coercive medical interventions such as requiring contraceptive sterilisation, sex reassignment surgery and/or unmarried status for legal recognition of gender identity change. Recognising that this violates the right to nondiscrimination and also human dignity, an increasing number of countries have found such laws unconstitutional. For example, in Germany the Federal Constitutional Court ruled that the law requiring individuals to be unmarried in order to change their gender identity was unconstitutional as it forced people to choose between the fundamental right of individual integrity and the right to marry (Federal Constitutional Court of Germany, 2008). In another case, the same court held that the requirements to undergo sterilisation and genital reconstructive surgery in order to achieve full legal recognition of a person's desired gender identity were incompatible with the constitutional right to sexual selfdetermination and physical integrity (Federal Constitutional Court of Germany, 2011). Similar decisions have been made by the Austrian Administrative High Court (2009) and the Italian Constitutional Court (1985).

Ready access to full and accurate information is essential for sexual health. Evidence from a range of countries indicates that information about sexuality and sexual health, imparted through comprehensive sexuality education can improve sexual health outcomes, including delaying sexual debut and reducing unintended pregnancies and sexual risk-taking (United Nations Educational, Scientific and Cultural Organization [UNESCO], 2009). Global policy standards affirm that sexuality education must include attention to gender equality and human rights (UNESCO, 2009). In 2006, African health ministers adopted a plan of action for realising sexual and reproductive health and rights, which includes sexuality education in and out of schools, as a key strategy (African Union, 2006). In 2008, health and education ministers from across Latin America and the Caribbean signed a historic declaration to stop HIV and STIs in the region through implementation and/or strengthening of multi-sector strategies for the provision of comprehensive sexuality education and promotion of sexual health (Ministers of Health and Education in Latin America and the Caribbean, 2008). 
Despite these developments, information about sexuality is still censored by many states, often with labels such as 'obscene' or 'indecent', especially when it comes to making that information available to adolescents under age 18 and/or people who are not married. International and regional human rights standards make clear, however, that children have the right to objective and scientifically supported information, in line with their evolving capacity, and that states have the duty to provide it (CRC, 2003a, 2003b, 2013).

The child's right to sexuality education was upheld, for example, by a European Court of Human Rights decision concerning sexuality education in Denmark where such education, appropriate to the student's level of maturity, has been a compulsory part of the curriculum since 1970. When six parents claimed that provision of sexuality education was contrary to their Christian beliefs and violated their rights as parents, the Court stated that, because students were given information in a correct, objective, precise and scientific manner, it did not violate the parents' rights to religious or philosophical convictions or their ability to convey these beliefs to their children (European Court of Human Rights [ECtHR], 1976).

\section{Accountability for sexual health and human rights}

Accountability is a key principle of human rights. It requires compliance by states with their obligations to bring their laws, policies and practices - including in relation to sexuality and sexual health - in line with international, regional and national human rights standards. The establishment of precise global standards, accessible and wellfunded monitoring mechanisms, redress and reparations for harm, and long-term followup, are key elements of accountability (Potts, 2008).

Law plays an important role in ensuring accountability at many levels including, among others, establishing transparent monitoring and review processes to record health outcomes across a sexually diverse population, or the impact of various health interventions. Such review processes can help identify laws that have harmful effects and/or that contradict human rights. In addition, social and political movements can play important roles in upholding or reforming laws to guarantee legal protection and fulfilment of sexual health and rights.

Core indicators to monitor sexual health, including some that track laws and protection (or not) of human rights, can provide a common approach to ensuring accountability for sexual health at national and international levels (WHO, 2010b). For example, for HIV, the fact that legal and policy commitments are included among the core indicators that countries must report on has helped to establish accountability for the impact of national legal environments on HIV prevention and control (Gruskin, Ferguson, Alfven, Rugg, \& Peersman, 2013).

At the national level, the system of parliamentary human rights committees is an example of a mechanism that can play an important role in determining whether draft laws, including those affecting sexual health, are in compliance with human rights before their submission to parliament, proposing the annulment of existing laws and elaborating new laws. Their effectiveness varies, depending on their mandates, power, scope, working methods and membership, but if they function well they can be important watchdogs for ensuring that laws are in conformity with human rights standards (The National Democratic Institute for International Affairs, 2004).

International and regional mechanisms such as the UN human rights treaty monitoring bodies also review state compliance with international, regional and national 
human rights standards, including as they relate to sexuality and sexual health. Other mechanisms include the UN Special Rapporteur on the right to health and the Special Rapporteur on torture, both of whom have recently reported human rights violations related to sexual health to the UN Human Rights Council and to the UN General Assembly (UN 2011b, 2013). Civil society organisations, some governments and other stakeholders have been influential in this work and continue to systematically urge the Human Rights Council to prioritise sexual health and related rights on its agenda (IPPF, 2012).

Human rights treaty bodies, including the Committee on Economic, Social and Cultural Rights (CESCR), the Human Rights Committee (HRC) and the Committee on Elimination of All Forms of Discrimination against Women (CEDAW), have begun to call on states to bring laws that have direct effects on sexual health into compliance with human rights standards. An example of their impact on national accountability mechanisms is reference to CEDAW's recommendations by the Constitutional Court in Colombia, when it ruled that abortion should not be considered a crime when the life or the physical or mental health of the woman is in danger, when pregnancy is a result of rape or incest, or in case of grave foetal malformations (Women's Link Worldwide, 2007).

Laws also guide development and implementation of remedies and redress for people whose human rights are violated. When the means to remedy violations do not exist or fail to work, progress towards realisation of sexual and reproductive health and rights cannot be made. Drawing on decades of experience, human rights bodies have elaborated the combination of measures that are required for full reparations: both short term, by establishing systems of redress through compensation and rehabilitation, for example; and longer term, such as legislative and health system reform to guarantee non-repetition of the failure (UN, 2001, 2005; WHO, 2011b). For example, in the case of L.C. v. Peru (2009), in which L.C. was denied a therapeutic abortion, CEDAW (2009) found that the state had failed in its obligations to protect health, private life and equality, by not establishing a legal framework requiring private and public health care providers to provide adequate care for the life and health of pregnant women.

\section{Conclusion: concrete steps beyond 2014}

Since the ICPD, human rights have been applied in many different ways to sexuality and sexual health, strengthening the meaning and content of sexual rights. A lot has been achieved but much remains to be done. On the basis of the existing international human rights standards, and often their own national laws, states have a responsibility to review and revise or elaborate laws to ensure that they reflect and uphold the human rights standards that have now been established related to sexuality and sexual health. While legal guarantees are essential, they are not sufficient. States must undertake a variety of other measures to ensure implementation of good laws and policies. For the promotion and protection of sexual health, these include:

- Development and implementation of protocols and standards for health care provision that adhere to human rights, such as safeguards for privacy and confidentiality, appropriate restrictions on conscientious objection in health service delivery and availability of essential medicines such as emergency contraception, among many others; 
- Budgetary allocations sufficient to ensure that the most marginalised - whether geographically or socio-economically - people are reached;

- Policy frameworks and action to ensure that the people whose health and lives are at stake have effective representation in decision-making;

- Education and training in human rights and their relationship to sexuality and sexual health, particularly for parliamentarians, law enforcement agencies and the judiciary; and

- Increased support for public education about sexual health and human rights, in ways that help to reduce discrimination; increase understanding of sexuality, gender equality and human rights; and encourage respect for human diversity.

Taking sexual health seriously requires engaging with law and human rights. A solid set of human rights standards now exists to use in assessing laws that affect sexuality. There is increasing evidence of how laws and their implementation (or not) affect sexual health, as well as a growing number of national and global accountability mechanisms that are being used to strengthen laws and practices. These factors, especially when used together, will improve sexual health and rights for all.

\section{Acknowledgements}

The authors wish to acknowledge the following experts who contributed to the collection of some of the information used in this article: Hossam Bhagat, Kajal Bhardwaj, Simone Cusack, Vivek Divan, Barbara Klugman, Charles Ngwena, Mindy J. Rosemann, Esteban Restrepo Saldarriaga, Carole Vance, Johanna Westeson.

\section{Disclosure statement}

No potential conflict of interest was reported by the author(s).

\section{Funding}

This work was carried out with the aid of a grant from Canada's International Development Research Centre.

\section{References}

African Union. (2003). Protocol to the African charter on human and peoples' rights on the rights of women in Africa (article 4(2)(a)). Maputo: Author.

African Union. (2006). Maputo plan of action for the operationalisation of the continental policy framework for sexual and reproductive health and rights 2007-2010 (Sp/MIN/CAMH/5(I)). Addis Ababa: Author.

Assembleia da Republica. (1976). Constituica Da Republica Portuguesa [Constitution of the Portuguese republic], constitution of the Portuguese republic, seventh revision [2005] article 67 s. 2.

Austrian Administrative High Court. (2009). VwGH 27.02.2009, 2008/17/0054, decided 27 February 2009.

Bartlett, L. A., Berg, C. J., Shulman, H. B., Zane, S. B., Green, C. A., Whitehead, S., \& Atrash, H. K. (2004). Risk factors for legal induced abortion-related mortality in the United States. Obstetrics \& Gynecology, 103, 729-737. doi:10.1097/01.AOG.0000116260.81570.60

Benoit, C., \& Millar, A. (2001). Dispelling myths and understanding realities: Working conditions, health status, and exiting experiences of sex workers. Victoria, BC: Prostitutes Empowerment, Education and Resource Society (PEERS).

Berer, M. (2004). National laws and unsafe abortion: The parameters of change. Reproductive Health Matters, 12(Suppl. 24), 1-8. doi:10.1016/S0968-8080(04)24024-1

Blankenship, K. M., \& Koester, S. (2002). Criminal law, policing policy, and HIV risk in female street sex workers and injection drug users. The Journal of Law, Medicine \& Ethics, 30, 548559. doi:10.1111/j.1748-720X.2002.tb00425.x 
Boland, R., \& Katzive, L. (2008). Developments in laws on induced abortion: 1998-2007. International Family Planning Perspectives, 34(3), 110-120. doi:10.1363/3411008

CEDAW. (1999). CEDAW general recommendation no. 24: Article 12 of the convention (women and health) (A/54/38/Rev.1, chap. I). New York, NY: United Nations.

CEDAW. (2002). Combined third and fourth period reports - Sri Lanka (chapter IV, section B.4, para. 285). Report of the committee on the elimination of discrimination against women Twenty-sixth and twenty-seventh sessions and exceptional session (A/57/38(SUPP)). New York, NY: United Nations.

CEDAW. (2009). Communication no. 22/2009: L.C. v. Peru (CEDAW/C/50/D/22/2009). New York, NY: United Nations.

CEDAW. (2010). General recommendation no. 28 on the core obligations of states parties under article 2 of the convention of the elimination of all forms of discrimination against women (CEDAW/C/GC/28). New York, NY: United Nations.

CEDAW. (2011). Communication no. 17/2008: Alyne Da Silva Pimentel Teixeira (deceased) v. Brazil (CEDAW/C/49/D/17/2008). New York, NY: United Nations.

CESCR. (2009). General comment no. 20: Non-discrimination in economic, social and cultural rights (art. 2, para. 2, of the international covenant on economic, social and cultural rights) (E/ C.12/GC/20). New York, NY: United Nations.

Committee on the Elimination of Discrimination against Women (CEDAW). (1992). CEDAW general recommendation no. 19: Violence against women (A/47/38). New York, NY: United Nations.

Commonwealth of Australia. (1994). Human rights (sexual conduct) Act 1994. Act No. 179 of 1994.

Commonwealth of Australia State of Victoria. (2006). Prostitution control regulations 2006, S.R. No. 64/2006.

Constitutional Tribunal of the Republic of Peru. (2006). Judgement $N^{\circ} 7435-2006-P C / T C$, decided 13 November 2006. para. 22 [in Spanish].

Cook, R. J., \& Dickens, B. M. (2008). Human rights dynamics of abortion law reform. Human Rights Quarterly, 25(1), 1-59. doi:10.1353/hrq.2003.0003

Council of Europe. (2011). Discrimination on grounds of sexual orientation and gender identity in Europe (2nd ed.). Strasbourg: Author.

Council of State of the Republic of Colombia. (2002). Judgement of 5 June 2008. Exp. 11001-0324-000-2002-00251-01, Bulletin No. 25, June 16/08: para. 2.2.2. [in Spanish].

Crago, A. L., Rakhmetova, A., Klaradafov, M., Islamova, S., \& Maslove, I. (2008). Central \& Eastern Europe and Central Asia: Police raids and violence put sex workers at risk of HIV. HIV/ AIDS Policy \& Law Review, 13(2-3), 71-72.

CRC. (2003a). General comment no. 4: Adolescent health and development in the context of the convention on the rights of the child (paras. 16, 28, 30) (CRC/GC/2003/4). New York, NY: United Nations.

CRC. (2003b). General comment no. 3: HIV/AIDS and the rights of the child (paras. 6, 9, 15-21) (CRC/GC/2003/3). New York, NY: United Nations CRC.

CRC. (2013) General comment No. 15: The rights of the child to the highest attainable standard of health. Geneva: United Nations Committee on the Rights of the Child; 2013. (UN Doc. CRC/C/ $\mathrm{GC} / 15)$.

David, H. P. (2002). Abortion in Europe, 1920-91 - A public-health perspective. Studies in Family Planning, 23(1), 1-22. doi:10.2307/1966824

Day, S., \& Ward, H. (2007). British policy makes sex workers vulnerable. BMJ, 334, 187. doi:10.1136/bmj.39104.638785.59

Dulitsky, A., \& Zimmerman, H. (2013). Case note: Indirect discrimination, reproductive rights and the in vitro fertilisation ban. The Equal Rights Trust Review, 10, 123-129.

ECtHR. (1981). Dudgeon v. United Kingdom (ser. A, no. 45). Application no. 7525/76, decided 22 October 1981. Strasbourg: Author.

ECtHR. (1995). C.R. v. the United Kingdom (para. 42). Application nos 20166/92 and 20190/92, decided 22 November 1995. Strasbourg: Author.

Ellertson, C., Ambardekar, S., Hedley, A., Coyaji, K., Trussell, J., \& Blanchard, K. (2001). Emergency contraception: Randomized comparison of advance provision and information only. Obstetrics and Gynecology, 98, 570-575. doi:10.1016/S0029-7844(01)01506-X 
England and Wales High Court of Justice. (2002). Smeaton v. Secretary of state for health (paras. 54-72). EWHC 610 (Admin), decided 18 April 2002.

European Court of Human Rights (ECtHR). (1976). Kjeldsen, Busk Madsen and Pederson v. Denmark. Application nos. 5095/71, 5920/72, 5926/72ecided 7 December 1976. Strasbourg: Author.

Federal Constitutional Court of Germany. (2008). 1 BvL 10/05, decided 27 May 2008.

Federal Constitutional Court of Germany. (2011). 1 BvR 3295/07, decided 11 January 2011.

Global Commission on HIV and the Law. (2012). HIV and the law: Risks, rights and health. New York, NY: UNDP.

Gruskin, S., Ferguson, L., Alfven, T., Rugg, D., \& Peersman, G. (2013). Identifying structural barriers to an effective HIV response: Using the national composite policy index data to evaluate the human rights, legal and policy environment. Journal of the International AIDS Society, 16, 18000. doi:10.7448/IAS.16.1.18000

Harper, C. C., Cheong, M., Rocca, C. H., Darney, P. D., \& Raine, T. R. (2005). The effect of increased access to emergency contraception among young adolescents. Obstetrics and Gynecology, 106, 483-491. doi:10.1097/01.AOG.0000174000.37962.a1

Hogerzeil, H. V., Samson, M., Casanovas, J. V., \& Rahmani-Ocora, L. (2006). Is access to essential medicines as part of the fulfilment of the right to health enforceable through the courts? The Lancet, 368, 305-311. doi:10.1016/S0140-6736(06)69076-4

India HIV/AIDS Alliance. (2011). Annual report 2010-2011: Supporting community action on AIDS in India. New Delhi: Author.

Inter-American Court of Human Rights. (2012, November 28). Caso Artavia Murillo y Otros (Fecundación IN VITRO) v. Costa Rica. Preliminary objections, merits, reparations and costs.

International Council on Human Rights Policy. (2009). Sexuality and human rights: Discussion paper. Versoix: Author. Retrieved from http://www.ichrp.org/en/projects/137

International Criminal Court (ICC). (2011). International criminal court assembly of states parties. Elements of crimes (ICC-PIDS-LT-03-002/11_Eng, Article 7(1)(g)-1)1). The Hague: Author.

International Criminal Court Assembly of States Parties. (2002). Rules of procedure and evidence (ICC-ASP/1/3, Rule 63(4)). New York, NY: International Criminal Court.

International Planned Parenthood Federation (IPPF). (2008). Sexual rights: An IPPF declaration. London: Author.

IPPF. (2012). Sexual rights and the universal periodic review: A toolkit for advocates. London: Sexual rights initiative and IPPF.

Itaborahy, L. P., \& Zhu, J. (2013). State-sponsored homophobia, a world survey of laws: Criminalisation, protection and recognition of same-sex love (8th ed.). International lesbian gay bisexual trans and intersex association [ILGA]. Retrieved from www.ilga.org

Italian Constitutional Court. (1985). Decision No. 161 of 1985.

Jackson, R. A., Schwarz, E. B., Freedman, L., \& Darney, P. (2003). Advance supply of emergency contraception. Effect on use and contraception - A randomized trial. Obstetrics and Gynecology, 102(1), 8-16. doi:10.1016/S0029-7844(03)00478-2

Jeffrey, L. A., \& Sullivan, B. (2009). Canadian sex work policy for the 21st century: Enhancing rights and safety, lessons from Australia. Canadian Political Science Review, 3(1), 57-76. Retrieved from http://ojs.unbc.ca/index.php/cpsr/article/view/48

Jewkes, R., Brown, H., Dickson-Tetteh, K., Levin, J., \& Rees, H. (2002). Prevalence of morbidity associated with abortion before and after legalisation in South Africa. BMJ, 324, 1252-1253. doi:10.1136/bmj.324.7348.1252

Jewkes, R., \& Rees, H. (2005). Dramatic decline in abortion mortality due to the choice on termination of pregnancy act. South African Medical Journal, 95, 250.

Jewkes, R., Rees, H., Dickson, K., Brown, H., \& Levin, J. (2004). The impact of age on the epidemiology of incomplete abortions in South Africa after legislative change. British Journal Obstetrics and Gynaecology, 112, 355-359. doi:10.1111/j.1471-0528.2004.00422.x

Joint United Nations Programme on HIV/AIDS (UNAIDS). (2013). Ending overly broad criminalisation of HIV non-disclosure, exposure and transmission: Critical scientific, medical and legal considerations (Guidance note). Geneva: Author.

Karandikar, S., \& Moises, P. (2010). From client to pimp: Male violence against female sex workers. Journal of Interpersonal Violence, 25, 257-273. doi:10.1177/0886260509334393 
Kingdom of Thailand. (2007). Criminal code amendment act (No.19) B.E. 2550. Bangkok: Social Division, Department of International Organizations, Ministry of Foreign Affairs, Kingdom of Thailand.

Lo, S. S., Fan, S. Y., Ho, P. C., \& Glaser, A. (2004). Effect of advanced provision of emergency contraception on women's contraceptive behaviour: A randomized controlled trial. Human Reproduction, 19, 2404-2410. doi:10.1093/humrep/deh425

Lovvorn, A., Nerquaye-Tetteh, J., Glover, E. K., Amankwa-Poku, A., Hays, M., \& Raymond, E. (2000). Provision of emergency contraceptive pills to spermicide users in Ghana. Contraception, 61, 287-293. doi:10.1016/S0010-7824(00)00107-4

Lutnick, A., \& Cohan, D. (2009). Criminalization, legalization or decriminalization of sex work: What female sex workers say in San Francisco, USA. Reproductive Health Matters, 17(34), 3846. doi:10.1016/S0968-8080(09)34469-9

Marston, C., Meltzer, H., \& Majeed, A. (2005). Impact on contraceptive practice of making emergency hormonal contraception available over the counter in Great Britain: Repeated cross sectional surveys. $B M J, 331,271$. doi:10.1136/bmj.38519.440266.8F

Mayhew, S., Collumbien, M., Qureshi, A., Platt, L., Rafiq, N., Faisel, A., ... Hawkes, S. (2009). Protecting the unprotected: Mixed-method research on drug use, sex work and rights in Pakistan's fight against HIV/AIDS. Sexually Transmitted Infections, 85(Suppl. 2), ii31-ii36. doi:10.1136/sti.2008.033670

Miller, J. (2002). Violence and coercion in Sri Lanka's commercial sex industry. Violence against Women, 8, 1044-1073. doi:10.1177/107780102401101737

Ministers of Health and Education in Latin America and the Caribbean. (2008, August 1). Ministerial declaration: Preventing through education. First meeting of Ministers of Health and Education to stop HIV and STIs in Latin America and the Caribbean, Mexico City, Mexico.

Moreau, C., Bajos, N., \& Trussell, J. (2006). The impact of pharmacy access to emergency contraceptive pills in France. Contraception, 73, 602-608. doi:10.1016/j.contraception.2006. 01.012

National Assembly of the Republic of Serbia. (2009). The law on the prohibition of discrimination. (Art. 2(1)). (Labris Serbia, Trans.). 'Official Gazette of RS', no. 22/09. Serbia: Author.

The National Democratic Institute for International Affairs. (2004). Establishing parliamentary committees. Rights consortium. Washington: Author.

New South Wales Government. (2001). Report of the brothels task force. Sydney: Author.

New Zealand Public Act. (2003). Prostitution reform act 2003. Public act 2003 No. 28.8(1).

O'Connor, C. C., Berry, G., Rohrsheim, R., \& Donovan, B. (1996). Sexual health and the use of condoms among local and international sex workers in Sydney. Genitourine Medicine, 72, $47-$ 51. doi:10.1136/sti.72.1.47

Organization of American States General Assembly. (2013). Inter-American convention against all forms of discrimination and intolerance (AG/RES.2804 (XLIII-O/13). Washington, DC: Organization of American States.

Pauw, I., \& Brener, L. (2003). 'You are just whores - you can't be raped': Barriers to safer sex practices among women street sex workers in Cape Town. Culture, Health \& Sexuality, 5, 465481. doi:10.1080/136910501185198

Portuguese Republic. (1999, August 11). Law no. 120/1999. Strengthening the guarantee of access to reproductive health (art. 3.2).

Portuguese Republic. (2000, October 17). Legal decree 259/2000 (art. 6).

Potts, H. (2008). Accountability and the right to the highest attainable standard of health. Colchester: University of Essex.

Reckart, M. L. (2005). Sex-work harm reduction. The Lancet, 366, 2123-2134. doi:10.1016/S01406736(05)67732-X

Republic of Fiji High Court. (2005). Nadan and McCoskar v. State. FJHC 500, decided 26 August 2005. Suva: Author.

Republic of South Africa. (1996). Constitution of the republic of South Africa. No. 108 of 1996, sections 27(1) and (2) section 27(3).

Republic of South Africa. (2007). Criminal law (sexual offences and related matters) amendment act 32 of 2007 (section 3). Pretoria: Author.

Republic of South Africa Constitutional Court. (1998). National coalition for gay and lesbian equality and another v. Minister of justice and others. Case CCT 11/98, decided 9 October 1998. 
Rutledge, S. E., Abell, N., Padmore, J., \& McCan, T. J. (2009). AIDS stigma in health services in the Eastern Caribbean. Sociology of Health Illness, 31(1), 17-34. doi:10.1111/j.1467-9566.2008. 01133.x

Sayles, J. N., Wong, M. D., Kinsler, J. J., Martins, D., \& Cunningham, W. E. (2009). The association of stigma with self-reported access to medical care and antiretroviral therapy adherence in persons living with HIV/AIDS. Journal of General Internal Medicine, 24, 11011108. doi:10.1007/s11606-009-1068-8

Snow, R. C., Laski, L., \& Massy, M. (2014). Sexual and reproductive health: Progress and outstanding needs. Global Public Health, 10(2). doi:10.1080/17441692.2014.986178

Soon, J. A., Levine, M., Osmond, B. L., Ensom, M. H. H., \& Fielding, D. W. (2005). Effects of making emergency contraception available without a physician's prescription: A populationbased study. Canadian Medical Association Journal, 172, 878-883. doi:10.1503/cmaj.045019

Supreme Court of the United Mexican States. (2010). Constitutional controversy 54/2009, decided 27 May 2010. Section IV [in Spanish].

Suvedi, B. K., Pradhan, A., Barnett, S., Puri, M., Chitrakar, S. R., Poudel, P., ... Hulton, L. (2009). Nepal maternal mortality and morbidity study 2008/2009: Summary of preliminary findings. Kathmandu: Family Health Division, Department of Health Services, Ministry of Health.

Temmerman, M., Khosla, R., \& Say, L. (2014). Sexual and reproductive health and rights: A global development, health, and human rights priority. The Lancet, 384, e30-e31. doi:10.1016/S01406736(14)61190-9

UN Committee on Economic, Social and Cultural Rights (CESCR). (2000). General comment no. 14: The right to the highest attainable standard of health (E/C.12/2000/4). New York, NY: United Nations.

UN Committee on the Rights of the Child (CRC). (2000). Optional protocol to the convention on the rights of the child on the sale of children, child prostitution and child pornography (A/RES/ 54/263), entered into force 18 January 2002. New York, NY: Author.

UN Human Rights Committee (HRC). (1994). Views on communication no. 488/1992: Toonen $v$. Australia (CCPR/C/50/D/488/1992). Geneva: United Nations.

UN. (1994). A/CONF.171/13/Rev.1 - Report of the international conference on population and development (para. 7.2 and 7.3). New York, NY: Author.

UN. (1996). Report of the fourth world conference on women, Beijing, September 4-15, 1995 (para. 96). New York, NY: Author.

UN. (2000). Protocol to prevent, suppress and punish trafficking in persons, especially women and children, supplementing the United Nations convention against transnational organized crime. New York, NY: Author.

UN. (2001). Commentary of the international law commission to article 34 of the draft articles on responsibility of states for internationally wrongful acts. Official records of the United Nations general assembly, fifty-sixth session, supplement No. 10 (A/56/10.2001). New York, NY: United Nations General Assembly.

UN. (2005). Basic principles and guidelines on the right to a remedy and reparation for victims of gross violations of international human rights law and serious violations of international humanitarian law (resolution 60/147 of 16 December 2005). New York, NY: United Nations General Assembly.

UN. (2010). Report of the special rapporteur on the right of everyone to the enjoyment of the highest attainable standard of physical and mental health, Anand Grover (A/HRC/14/20). New York, NY: United Nations General Assembly.

UN. (2011a). Report of the United Nations high commissioner for human rights, discriminatory laws and practices and acts of violence against individuals based on their sexual orientation and gender identity (A/HRC/19/41). Geneva: United Nations General Assembly.

$\mathrm{UN}$. (2011b). Interim report of the special rapporteur on the right of everyone to the enjoyment of the highest attainable standard of physical and mental health (A/66/254). New York, NY: United Nations General Assembly.

UN. (2013). Report of the special rapporteur on torture and other cruel, inhuman or degrading treatment or punishment, Juan E. Méndez (A/HRC/22/53). New York, NY: United Nations General Assembly.

United Nations (UN). (1966). International covenant on economic, social and cultural rights. New York, NY: Author. 
United Nations Economic Commission for Latin America and the Caribbean (UNECLAC). (2013). Montevideo consensus on population and development (August 15, 2013). Montevideo: Author.

United Nations Educational, Scientific and Cultural Organization (UNESCO). (2009). International technical guidance on sexuality education. Paris: Author.

WHO. (2005a). Researching violence against women: A practical guide for researchers and activists. Geneva: WHO, and Seattle: Program for Appropriate Technology in Health.

WHO. (2005b). Emergency contraception. Fact sheet No. 244. Geneva: Author.

WHO. (2006). Defining sexual health: Report of a technical consultation on sexual health, 28-31 January 2002, Geneva. Geneva: Author.

WHO. (2008). World health report 2008 - Primary health care: Now more than ever. Geneva: Author.

WHO. (2010a). Developing sexual health programmes: A framework for action (WHO/RHR/HRP/ 10.22). Geneva: Author.

WHO. (2010b). Measuring sexual health: Conceptual and practical considerations and related indicators. Geneva: Author.

WHO. (2011a). Model list of essential medicines (17th ed.). Geneva: Author.

WHO. (2011b). Keeping promises, measuring results. Commission on information and accountability for women's and children's health. Geneva: Author.

Women's Link Worldwide. (2007). Excerpts of the constitutional court's ruling that liberalized abortion in Colombia. Women's link worldwide. Retrieved from http://www.womenslinkworld wide.org/pdf_pubs/pub_c3552006.pdf

World Association for Sexual Health (WAS). (2014). Declaration of sexual rights. Retrieved from http://www.worldsexology.org/resources/declaration-of-sexual-rights/

World Health Organization (WHO). (2004). Reproductive health strategy to accelerate progress towards the attainment of international development goals and targets. Global strategy adopted by the 57th world health assembly. Geneva: Author. 